\title{
The Effects of Servant Leadership on Employee's Job Withdrawal Intention
}

\author{
Xin Le $\mathrm{Ng}^{1}$, Sang Long $\mathrm{Choi}^{2} \&$ Khairiah Soehod ${ }^{1}$ \\ ${ }^{1}$ Faculty of Management, Universiti Teknologi Malaysia, Johor, Malaysia \\ ${ }^{2}$ International Business School, Universiti Teknologi Malaysia, Johor, Malaysia \\ Correspondence: Xin Le Ng, Universiti Teknologi Malaysia, Johor, Malaysia. E-mail: Iriss89@gmail.com
}

\author{
Received: November 25, 2015 Accepted: December 17, 2015 Online Published: January 12, 2016 \\ doi:10.5539/ass.v12n2p99 \\ URL: http://dx.doi.org/10.5539/ass.v12n2p99
}

\begin{abstract}
This study employed survey research to investigate the effects of servant leadership on employee job withdrawal intention. Employees are valuable assets to organization. Leaders are important to decrease employee's job withdrawal intention. Servant leadership style is important to build a good relationship with their employees. Respondents consist of employees that work at small medium enterprises in Johor Bahru, Malaysia. Using questionnaires to collect data and AMOS to analyze data. The results reveal a negative relationship between servant leadership and employee's job withdrawal intention. Thus, it provides evidence that servant leadership is able to reduce employee's job withdrawal intention. This study provides some ideas for leader on how to retain quality workers.
\end{abstract}

Keywords: servant leadership, employee job withdrawal intention, small medium enterprises

\section{Introduction}

An abundance of studies has been done to know the reasons of employee job withdrawal intention. Employee's job withdrawal intention or employee's turnover intention is a costly problem for organizations. It is interesting to note that salary pay becomes a less important criterion to influence job turnover. This has been proven by several scholars, and Khatri, Fern, and Budhwar (2001) identified that in the food and beverage and the marine and shipping industries, the salary was not an important concern for the employees. Rubiah (2012) listed external opportunity, limited growth opportunities and further studies as the three main reasons for employees to leave an organization. Recent evidence also shows that turnover intention can be influenced by many factors, including job dissatisfaction as well as poor leadership (Bull, 2010).

Recently, leaders are more stressful to build a good relationship with their followers. Many decades ago, researchers believe that leaders are more autocratic while nowadays leaders are seen to be more democratic (Boyum, 2012). In this context, it is increasingly difficult to ignore the importance of the practice of servant leadership. There is an enormous number of articles regarding servant leadership. Many of the organizations made to the Fortune Magazine's annual listing of "The 100 Best Companies to Work For" is practicing servant leadership (Spears, 2010).

There are abundance of research that are related to leadership and employee turnover intention. However, there is still a lack of research specifically on servant leadership in Malaysia. The aim of the study is to examine the influence of servant leadership style on employee's job withdrawal intention in Johor Bahru, one of the cities in Malaysia.

\section{Literature Review}

\subsection{Servant Leadership}

Servant leaders empower employees in decision making, practices ethical and caring behavior, and enhances the growth of employees while improving the caring and quality of organizational life (Spears, 2010). Patterson (2003) and Franklin (2010) define servant leadership as a leadership that has its primary focus on followers whereas organizational concerns are secondary. In other words, servant leadership pays great attention to the well-being of followers (Meyer, Stanley, Herscovitch, \& Topolnytsky, 2002). Servant leaders employ a combination of characteristics, one of these characteristics is that they put employee as their priority. Greenleaf 
(1977), the pioneer in defining servant leadership, believes that a leader that practises servant leadership styles will place serving others' needs as their top priority. Ebener and O'Connell (2010) point out that servant leaders create a culture of service in organizations and have an impact on the beliefs, assumptions, values, and behaviors of the employees. Wong and Davey (2007) further explained that servant leaders are willing to serve in order to train employees into future leaders. Apart from that, the willingness of servant leaders to serve aims to meet followers' needs in all aspects (Sun \& Wang, 2009). In order to train employees into leaders, servant leaders will empower them (Van Dierendonck \& Nuijten, 2011). The culture of service comes with empowerment (Ebener \& O'Connell, 2010). Empowerment is one of an important components of servant leadership, where it allows employees to make decisions and learn new things, at the same time remaining the organizational competitiveness, increasing the organizational performance and making the working process more effective (Fernandez \& Moldogaziev, 2013). Other than giving authority for decision-making, leaders' communication skills are strongly needed. They need to be active in listening to others. Through listening, a servant leader will be able to identify the needs of their employees and take action to fulfill their needs (Spears, 2010). Besides, servant leaders learn when employees share their ideas (Boone \& Makhani, 2013). Another characteristic of servant leadership is being forgiving. This means a servant leader has also empathy and sympathy, and understands their feelings. In this case, employees are free to make mistakes. Employees will become more creative in making decisions to solve problems. This will help the organization to have the best employees (Van Dierendonck \& Nuijten, 2011). Servant leaders have low self-focus because they do self-assessments (Dennis, 2004) and know how to respect the worth of their employees (Hirschy, 2011). Den Hartog and De Hoogh (2009) also found that employees will trust their leaders and be committed to the organization if the leaders behave ethically.

There are different culture that may influence leadership practices such as culture that influenced by Confucian ideology or Islamic moral (House, Hanges, Javiden, Dorfman, \& Gupta, 2004). In Western countries, servant leadership is less practiced by leaders in Italy than in the Netherlands and the United Kingdom, particularly in the case of standing back, humility and authenticity (Bobbio, Van Dierendonck, \& Manganelli, 2012). House et al. (2004) group these three countries (Italy, Netherlands and United Kingdom) in different society cluster due to these countries have different culture background and histories. Researchers claim that in the Italian culture, these characteristics are seen as a threat to the position of a leader (Bobbio et al., 2012). Similarities and differences of the concept of servant leadership do not only occur among European countries, but also among both Eastern and Western countries. The idea of servant leadership can be defined by Christianity. Ebener and O'Connell (2010) also listed out some well-known figures whose ideologies are similar to servant leadership such as Mohandas Gandhi, Confucius and Laozi. In China, servant leadership has many similarities with Western servant leadership. However, it is suggested that Chinese servant leaders include the components of Confucianism, Daoism and Communist ideology in the development and formulation of Chinese servant leadership (Han, Kakabadse, \& Kakabadse, 2010). The servant leadership concept can be found in ancient Chinese text 'Tao Te Ching' by Laozi, which is a Chinese classic text regarding the way of life. In the text, Laozi advised leaders not to control followers. Another Chinese classic text ' $\mathrm{Di} \mathrm{Zi}$ Gui' also indicated that leaders need to treat their workers with benevolence. Furthermore, leaders need to treat their employees with good ethics, so that the employees can be influenced to become ethical beings (Zhang, 2006). The ideology of Confucianism is similar to servant leadership, which includes the elements of love, altruism, kindness (Winston \& Ryan, 2008). Precisely, due to the presence of Confucianism, Chinese organizations are still lack of egalitarianism compared to Western organizations, as Confucianism possesses hierarchical relationships and obedience. Companies in Western countries such as Finland are practicing more equality in the society (Mittal \& Dorfman, 2012). In the Islamic perspective, Mahazan et al. (2015) found similarities in servant leadership; for example, leaders should understand what criteria that a leader needs in this new era and to be effective. Abeng (1997) indicates that Muslim leaders are stress on honesty, integrity and fairness. In short, different cultures create different leadership practices but the core of leadership are similar.

Wong and Davey (2007) recommended leaders to practice servant leadership styles as this is suitable to create an organization which is more strength-based and meaning-centered. Servant leadership is not mechanical but humanistic. It is able to create a working environment that is caring and supportive. Overall, the main difference of servant leadership from other leadership models is that servant leadership concentrates on the humble and ethical use of power by the servant leader, cultivating a genuine relationship between leaders and followers as well as creating a supportive and a positive work environment. Spears (2002) points out that many leaders are starting to practice servant leadership as they believe servant leadership will bring positive long-term impact to the organization such as quality improvement. Starbucks Coffee Company is one of the companies that practice servant leadership. Lately, they provide free college education to their employees. Starbucks's CEO, Howard 
Schultz mentions that an organization cannot only focus on profitability; companies need to do more for their people and the communities they serve. Clearly, Howard Schultz knows the benefits of practicing servant leadership (Lichtenwalner, 2014).

\subsection{Turnover Intention}

Turnover can be defined as an individual's movement from an organization across the membership boundary. The term "turnover" also can mean quitting or exiting (Perez, 2008). Mobley (1982) stated that turnover is a scenario where an employee leaves the organization and it is a major phenomenon and persistent problem (Watrous, Huffman, \& Pritchard, 2006) in an organization. It can also be defined as the employee's termination of membership in an organization that he/she is serving and receives monetary compensation from the organization. Nevertheless, turnover intention leads to wasted money (Duffield, Roche, Blay, \& Stasa, 2011; R. B. Harris, Harris, \& Harvey, 2008).

Whitmore (1979) proposed a model to show the phenomena of labour turnover. It became a foundation for many scholars to study employee turnover. In his conceptual model, he shows the relationship between employment experience and the length of service. He also proposed that an employee may leave his organization if he/she is experiencing declining job attachment. When the employee reaches the separation threshold, the employee will leave the organization. However, if the employee has different experiences in the job environment, the employee's level of job attachment will increase, which means the employee will have longer lengths of services in the organization. Mobley, Horner, and Hollingsworth (1978) proposed a model of turnover by showing several main variables, which include age, tenure, job satisfaction, thinking of quitting, intention to search, intention to quit, the probability of finding an acceptable alternative, and quit. Mobley et al. identified that job satisfaction indirectly affects job turnover through affecting the thinking to quit, employees' intention to search, and intention to quit.

Mobley, Griffeth, Hand, and Meglino (1979) also presented a complex model for turnover. Indeed, intention to search and turnover intention have strong relationships with turnover behavior. Additionally, job satisfaction is still a main criterion that affects turnover intention. Besides, job expectations for the future will also affect the turnover intention of employees. In this concept, an employee who is unsatisfied with his job may still be attracted to his current job because of his opinion that the job can lead him to achieve his career goal in the future. Undeniably, apart from the two main criteria mentioned earlier, the alternatives available for the employees are also reasons for the employees to have the intention to quit. If the alternatives are able to lead the employees to a better future, the employees will have the intention to turnover. Organizational variables that are perceived by the employees, which include supervision, climate, economic-labour market that include vacancy rate and individual-level occupational and personal variables also affect the three main variables (job satisfaction, job expectations for the future and alternatives available for the employees) that lead to turnover intention.

\subsection{Relationship between Servant Leadership and Turnover Intention}

Wong and Davey (2007) stated that servant leaders did focus on employee retention and development. In recent years, there has been an increasing amount of literature on the impact of servant leadership on employee's withdrawal intention. Caffey (2012) focused her research on the retention of new teachers who worked for less than 5 years. In her study, she used the Servant Leadership Assessment Instrument and Servant Leadership Relational Assessment to measure her variables and the survey forms were distributed to 123 new teachers. She identified that school principals that display servant leadership styles incorporating characteristics of empowerment and humility will lead to higher teacher retention. On the other hand, Elci, Sener, Aksoy, and Alpkan (2012) conducted a study involving 1093 employees in 70 firms from 9 different industries including pharmaceuticals, finance, and manufacturing. They found out that having an ethical leader decreases the employee's turnover intention. Jaramillo, Grisaffe, Chonko, and Roberts (2009) provide an overview of servant leadership and sales forces turnover intention. They identified that servant leaders help to create a positive work climate where salespeople may feel a stronger sense of shared organizational values, leading to a higher commitment to the organization, and thus reducing their intention to withdraw from the workplace. In their analysis, they also concluded that the ethical behavior of leaders is another point to create a positive work climate. In another study, R. B. Harris et al. (2008) found that ethical behavior of leaders gives impact on the employee's turnover rate. This research also suggests that even facing job stress, the employee's turnover intention will decrease when they have support from leaders. Using 231 employees as their sample, the study revealed that when supervisors are willing to back up their subordinates, act ethically and empower their subordinates, the turnover intention of the employees will decrease.

De Cremer (2006) explained the relationship between a leader standing back and empowering and employee 
retention. 103 students from a Dutch university participated in this research. They were involved in a scenario experiment and a laboratory experiment. Results showed that employees are more willing to stay with leaders who always serve and empower. Researchers also agreed that followers are more motivated to cooperate in groups with leaders who are always ready to serve. K. J. Harris, Wheeler, and Kacmar (2009) also studied the impact of empowerment on employee's turnover intention. The study showed that empowerment is a useful tool to decrease employee's turnover rate. Additionally, knowledge workers are very important to an organization and it is crucial to retain them. Joo (2010) performed a study on the effect of leaders on the retention of knowledge employees. Different industries in Korea were involved in this study and an instrument was designed to measure these variables. Results showed that leaders who are willing to serve, has trust, empathy and empowerment will positively affect the employee retention. Subsequently, Duffield et al. (2011) analyzed the effect of leadership characteristics among managers on staff satisfaction and retention. They conducted this study in 21 public hospitals in Australia. 2488 nurses completed the survey forms where they were required to rate their managers. The investigation showed that leaders who are willing to have communication with their employees will increase the employee retention in the workplace.

Also, G. Han and Jekel (2011) investigated the relationship between the leaders and nurses turnover intention in the nursing field. This research was conducted in a non-profit health care centre in the United States. 400 nurses from seven different units of the hospital in three locations were involved in this study. This study confirmed that leaders who recognize employees' efforts, understand their problems and situations, listen to their suggestions and help employees when needed will decrease the employee's turnover rate. Cowden, Cummings, and Profetto - Mcgrath (2011) has also done a similar research in the nursing field, where they discovered that leaders have to devote time and energy to serving employees in order to retain staff.

Thus, the hypothesis of this research is as follows:

Servant leadership is positively related to employee's withdrawal intention.

\section{Research Framework}

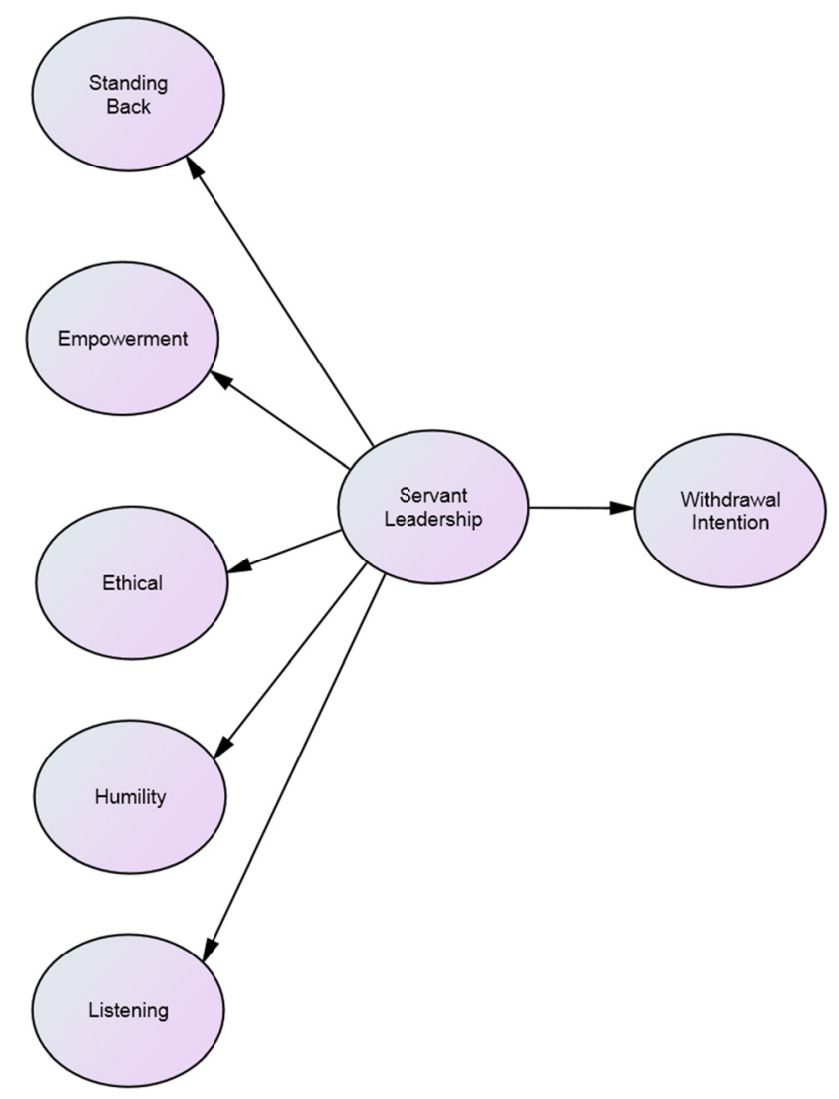

Figure 1. Research framework 
This study intends to study how servant leadership affects employee withdrawal intention. The characteristics of servant leadership include standing back, empowerment, ethics, humility and listening as in Figure 1.

\section{Study Design}

\subsection{Measure of Servant Leadership}

Respondents are asked how they perceive the characteristics of their leader. To measure this concept, researchers adapted questionnaire from Van Dierendonck and Nuijten (2011), Dennis and Bocarnea (2005), Reed, Vidaver-Cohen, and Colwell (2011), Laub (1999), and Rennaker (2008). Respondents are asked to rate each questions on a 5 point Likert scale (1-5) where 1 means strongly disagree and 5 means strongly agree. Confirmatory factor analyses resulted are RMSEA $=0.078, \mathrm{CFI}=0.908$, Chisq $/ \mathrm{df}=1.653$, which means this model achieves the level of acceptance for the fitness index.

\subsection{Measure of Employee Withdrawal Intention}

Respondents are also asked for their withdrawal intention in the organization. This scale content 7 questions where questions are adapted from Mobley et al. (1978) . 5 point Likert scale ranging from 1 to 5.1 means strongly disagree and 5 means strongly agree. Result of confirmatory factor analyses are RMSEA $=0.1, \mathrm{GFI}=$ $0.927, \mathrm{CFI}=0.969, \mathrm{Chisq} / \mathrm{df}=2.152$. All index achieve the level of acceptance.

\subsection{Procedure}

A survey for this research is conducted in Johor Bahru, Malaysia. There are two ways to distribute questionnaire which are online questionnaire survey using Google Forms and also hardcopy questionnaire sent by mail and hand-delivering. In total, 180 invitations to fill up the questionnaires were sent and 109 completed surveys were returned. The questionnaires are written in three languages specifically in English, Chinese and Malay language. All of the variables are measured on a scale ranging from 1 to 5 , with "1" means 'strongly disagree' and " 5 " is 'strongly agree'.

\section{Result and Discussion}

Table 1. Relationship between servant leadership and withdrawal intention

\begin{tabular}{llll}
\hline & & Estimate & p \\
\hline Withdrawal Intention $<----$ & Servant Leadership & -0.502 & $<0.001$ \\
\hline
\end{tabular}

Table 1 shows the relationship between servant leadership and withdrawal intention. Our hypothesis is support by the result. Servant leadership has a significant negative effect on employee withdrawal intention $(\beta=-0.502, p$ $<0.001$ ), which means when the leader behaves more to servant leadership style, the employee has less intention to leave the organization. In other word, servant leadership is able to reduce employee's job withdrawal intention. This result is similar with numerous past studies, for example the study done by Jaramillo et al. (2009), where he concluded that a servant leader can affect the employee's withdrawal intention. Additionally, servant leaders can increase the ethical climate in organizations. This is very important for leaders to have long-run-relationships with their employees. Ethical behavior also builds mutual trust between two parties (Patterson, 2003). Wong and Davey (2007) also indicate that servant leaders are deeply rooted in ethical values. They also suggested that listening is an important skill for leaders to know what is needed by their employees and their valuable ideas.

Jobstreet (one of the largest job search websites in Singapore) has done a survey based on 989 respondents, which indicates that $64 \%$ of respondents are likely to change their jobs if they cannot have good relationships with their leaders even if they are paid with high salary. Appreciation by leaders is important to make employees feel satisfied in their jobs (Jobstreet, 2015). This result further supports this study where one of the elements in servant leadership is included standing back. By standing back, leaders are willing to give credit to their employees. Joo (2010) showed that empowerment to employees lead to better relationships between employees and leaders.

\section{Conclusion}

In general, it can be suggested that leaders are influential in reducing the intention of employees to withdraw from organizations. Through many practices such as establishing ethical practices within the organizations, leaders can reduce employee's withdrawal intention. Leaders who demonstrate ethical behavior, decisions, and actions are able to gain trust from their employees. Apart from that, leaders also need to pay attention to what 
their employees are trying to say. Employees are valuable people that can share ideas with the leaders to benefit organizations. While the employees are sending out their messages, leader can also learn from them. Servant leaders should also admit their limitations and be willing to learn from their followers. When their employees share an important idea or finish an important task, a servant leader does not take credit from the employees. Furthermore, servant leaders are willing to sacrifice their own needs to fulfil the employees' needs. They also give authority to employees in making decisions. Training and empowering new leaders is also one of the targets of servant leaders.

\section{Future Research}

This study has limitations that can serve as recommendations for further research. Firstly, further research is needed to investigate the moderator or mediator that exists between leadership styles and employee turnover intention. Next, respondents from other fields may be included, such as the education field in Malaysia. Moreover, this research is only based on questionnaires. Respondents may misinterpret some keywords in questionnaires and lead to inaccuracy of the results. It is better to conduct face to face interviews to allow the interviewer to clarify the questions. Furthermore, conducting interviews with respondents can offer deeper insights into what the employees are looking for in their jobs and why they leave organizations.

\section{References}

Abeng, T. (1997). Business ethics in Islamic context: Perspectives of a Muslim business leader. Business Ethics Quarterly, 7(3), 47-54.

Bobbio, A., Van Dierendonck, D., \& Manganelli, A. M. (2012). Servant leadership in Italy and its relation to organizational variables. Leadership, 8(3), 229-243. http://dx.doi.org/10.1177/1742715012441176

Boone, L. W., \& Makhani, S. (2013). Five Necessary Attitudes of a Servant Leader. Review of Business, 83-96.

Boyum, V. S. (2012). A Model of Servant Leadership in Higher Education (Doctor of Philosophy). University of Minnesota, United States.

Bull, D. A. (2010). Situational Leadership Style and Employee Turnover Intent: A Critical Examination Of Healthcare Organizations (Doctor of Philosophy). Capella University, US.

Caffey, R. D. (2012). The Relationship between Servant Leadership of Principals and Beginning Teacher Job Satisfaction and Intent to Stay (Doctor of Education). University of Missouri-Columbia.

Cowden, T., Cummings, G., \& Profetto - Mcgrath, J. (2011). Leadership practices and staff nurses' intent to stay: a systematic review. Journal of Nursing Management, 19(4), 461-477. http://dx.doi.org/10.1111/j.13652834.2011.01209.x

De Cremer, D. (2006). Affective and motivational consequences of leader self-sacrifice: The moderating effect of autocratic leadership. The Leadership Quarterly, 17(1), 79-93. http://dx.doi.org/10.1016/j.leaqua.2005. 10.005

Den Hartog, D. N., \& De Hoogh, A. H. (2009). Empowering behaviour and leader fairness and integrity: Studying perceptions of ethical leader behaviour from a levels-of-analysis perspective. European Journal of Work and Organizational Psychology, 18(2), 199-230. http://dx.doi.org/10.1080/13594320802362688

Dennis, R. S. (2004). Servant Leadership Theory: Development of the Servant Leadership Assessment Instrument (Doctor of Philosophy). Regent University, United States.

Dennis, R. S., \& Bocarnea, M. (2005). Development of the servant leadership assessment instrument. Leadership \& Organization Development Journal, 26(8), 600-615. http://dx.doi.org/10.1108/01437730510633692

Duffield, C. M., Roche, M. A., Blay, N., \& Stasa, H. (2011). Nursing unit managers, staff retention and the work environment. Journal of clinical nursing, 20(1-2), 23-33. http://dx.doi.org/10.1111/j.1365-2702.2010. 03478.x

Ebener, D. R., \& O'Connell, D. J. (2010). How might servant leadership work? Nonprofit Management and Leadership, 20(3), 315-335. http://dx.doi.org/10.1002/nml.256

Elci, M., Sener, İ., Aksoy, S., \& Alpkan, L. (2012). The Impact of Ethical Leadership and Leadership Effectiveness on Employees' Turnover Intention: The Mediating Role of Work Related Stress. Procedia Social and Behavioral Sciences, 58, 289-297. http://dx.doi.org/10.1016/j.sbspro.2012.09.1003

Fernandez, S., \& Moldogaziev, T. (2013). Using Employee Empowerment to Encourage Innovative Behavior in the Public Sector. Journal of Public Administration Research and Theory, 23(1), 155-187. 
http://dx.doi.org/10.1093/jopart/mus008

Franklin, S. D. (2010). The Influence of Spirituality on Servant Leadership among Small Business Entrepreneurs (Doctor of Philosophy). Walden University, United States.

Greenleaf, R. K. (1977). Servant leadership. Mahwah, NJ: Paulist Press.

Han, G., \& Jekel, M. (2011). The mediating role of job satisfaction between leader-member exchange and turnover intentions. Journal of Nursing Management, 19, 41-49. http://dx.doi.org/10.1111/j.1365-2834.2010. 01184.X

Han, Y., Kakabadse, N. K., \& Kakabadse, A. (2010). Servant leadership in the People's Republic of China: A case study of the public sector. Journal of Management Development, 29(3), 265-281. http://dx.doi.org/10. $1108 / 02621711011025786$

Harris, K. J., Wheeler, A. R., \& Kacmar, K. M. (2009). Leader-member exchange and empowerment: Direct and interactive effects on job satisfaction, turnover intentions, and performance. The Leadership Quarterly, 20(3), 371-382. http://dx.doi.org/10.1016/j.leaqua.2009.03.006

Harris, R. B., Harris, K. J., \& Harvey, P. (2008). An examination of the impact of supervisor on the relationship between job strains and turnover intention for computer workers. Journal of Applied Social Psychology, 38(8), 2108-2131. http://dx.doi.org/10.1111/j.1559-1816.2008.00383.x

Hirschy, M. J. (2011). Servant Leadership in China: An Exploration of Servant Leadership, Humane Orientation, and Confucian Doctrine of Jen (Doctor of Philosophy in Organizational Leadership). Regent University, US.

House, R. J., Hanges, P. J., Javiden, M., Dorfman, P. W., \& Gupta, V. (2004). Culture, Leadership, and Organizations. United States: Sage Publication.

Jaramillo, F., Grisaffe, D. B., Chonko, L. B., \& Roberts, J. A. (2009). Examining the impact of servant leadership on salesperson's turnover intention. Journal of Personal Selling and Sales Management, 29(4), 351-366. http://dx.doi.org/10.2753/PSS0885-3134290404

Jobstreet. (2015). 6 In 10 Singaporeans Choose Better Boss Over Higher Pay. Retrieved May 13, 2015, from http:/www.jobstreet.com.sg/career-resources/6-10-singaporeans-choose-better-boss-higher-pay/

Joo, B. K. (2010). Organizational Commitment for Knowledge Workers: The Roles of Perceived Organizational Learning Culture, Leader-Member Exchange Quality, and Turnover Intention. Human Resource Development Quarterly, 21(1), 69-85. http://dx.doi.org/10.1002/hrdq.20031

Khatri, N., Fern, C. T., \& Budhwar, P. (2001). Explaining employee turnover in an Asian context. Human Resource Management Journal, 11(1), 54-74.

Laub, J. A. (1999). Assessing the servant organization: Development of the Servant Organizational Leadership Assessment (SOLA) instrument (Doctor of Education). Florida Atlantic University, Florida.

Lichtenwalner, B. (2014). Starbucks Demonstrates Servant Leadership with Free Education. Retrieved May 3, 2015, from http://modernservantleader.com/servant-leadership/starbucks-free-education/

Mahazan, A., Azdi, W. W. M. F., Aishah, H. S., Yuseri, A., Rosmizi, A. M., Yusuf, K. M., \& Rumaizuddin, M. (2015). Leadership Behaviors in Islam: Integrating Managerial Leadership and Servant Leadership. Middle-East Journal of Scientific Research, 23(4), 722-728.

Meyer, J. P., Stanley, D. J., Herscovitch, L., \& Topolnytsky, L. (2002). Affective, continuance, and normative commitment to the organization: A meta-analysis of antecedents, correlates, and consequences. Journal of vocational behavior, 61(1), 20-52. http://dx.doi.org/10.1006/jvbe.2001.1842

Mittal, R., \& Dorfman, P. W. (2012). Servant leadership across cultures. Journal of World Business, 47(4), 555-570. http://dx.doi.org/10.1016/j.jwb.2012.01.009

Mobley, W. H. (1982). Employee turnover: causes, consequences, and control. Mass: Addison-Wesley.

Mobley, W. H., Griffeth, R. W., Hand, H. H., \& Meglino, B. M. (1979). Review and conceptual analysis of the employee turnover process. Psychological Bulletin, 86(3), 493. http://dx.doi.org/10.1037/0033-2909.86. 3.493

Mobley, W. H., Horner, S. O., \& Hollingsworth, A. T. (1978). An evaluation of precursors of hospital employee turnover. Journal of Applied Psychology, 63(4), 408. http://dx.doi.org/10.1037/0021-9010.63.4.408 
Patterson, K. A. (2003). Servant Leadership: A Theoretical Model (Doctor of Philosophy). Regent University, US.

Perez, M. (2008). Turnover Intent (Diploma). University of Zurich, Brüttisellen.

Reed, L., Vidaver-Cohen, D., \& Colwell, S. (2011). A New Scale to Measure Executive Servant Leadership: Development, Analysis, and Implications for Research. Journal of Business Ethics, 101(3), 415-434. http://dx.doi.org/10.1007/s10551-010-0729-1

Rennaker, M. A. (2008). Listening and persuasion: Examining the communicative patterns of servant leadership (Doctor of Philosophy). Regent University, US.

Rubiah, A. R. (2012). A Study on Turnover Intention Trend In Commercial Banks In Penang, Malaysia (Master Degree). University Sains Malaysia, Malaysia.

Spears, L. C. (2002). Tracing the past, present, and future of servant-leadership. Focus on leadership: Servant-leadership for the twenty-first century, 1-16.

Spears, L. C. (2010). On character and servant-leadership: Ten characteristics of effective, caring leaders. The Journal of Virtues \& Leadership, 1(1), 25-30.

Sun, J. M., \& Wang, B. Y. (2009). Servant Leadership In China: Conceptualization And Measurement. Advances in Global Leadership, 5, 321-344). Emerald Group Publishing Limited.

Van Dierendonck, D., \& Nuijten, I. (2011). The servant leadership survey: Development and validation of a multidimensional measure. Journal of Business and Psychology, 26(3), 249-267. http://dx.doi.org/10.1007/ s10869-010-9194-1

Watrous, K. M., Huffman, A. H., \& Pritchard, R. D. (2006). When coworkers and managers quit: The effects of turnover and shared values on performance. Journal of Business and Psychology, 21(1), 103-126. http://dx.doi.org/10.1007/s10869-005-9021-2

Whitmore, G. (1979). An inverse Gaussian model for labour turnover. Journal of the Royal Statistical Society. Series A (General), 468-478. http://dx.doi.org/10.2307/2982553

Winston, B. E., \& Ryan, B. (2008). Servant leadership as a humane orientation: Using the GLOBE study construct of humane orientation to show that servant leadership is more global than western. International Journal of Leadership Studies, 3(2), 212-222.

Wong, P. T., \& Davey, D. (2007). Best practices in servant leadership. Servant Leadership Research Roundtable, School of Global Leadership and Entrepreneurship, Regent University.

Zhang, W. C. (2006). Di Zi Gui. China: Qingdao Chu Ban Sha.

\section{Copyrights}

Copyright for this article is retained by the author(s), with first publication rights granted to the journal.

This is an open-access article distributed under the terms and conditions of the Creative Commons Attribution license (http://creativecommons.org/licenses/by/3.0/). 